Journal of Educational

Technology \& Online Learning

Volume 4 | Issue 3 |2021

http://dergipark.org.tr/jetol

\title{
Project-based online learning experiences of pre-service teachers
}

\author{
Ayse Taskiran ${ }^{a *}$ (D) \\ a Anadolu University, Turkey.
}

Suggested citation: Taskiran, A. (2021). Project-based online learning experiences of pre-service teachers. Journal of Educational Technology and Online Learning, 4(3), 391-405

\begin{tabular}{l} 
Article Info \\
\hline Keywords: \\
Project-based learning \\
Online learning \\
Student-centered learning \\
Group-based learning \\
Collaboration
\end{tabular}

Research Article

\begin{abstract}
Student-centered learning approach, which embodies shifting the focus of instruction from teacher to student, actively engages students in their own learning process by incorporating their learning skills and interests. With the developments in instructional technologies making online learning widespread, the student-centered learning approach has found the opportunity to transition from theory to practice. How project-based learning, which is one of the best application areas of student-centered learning, can be realized in online learning environments and the views of pre-service teachers about this experience are the research subjects of this study. Conducted as a descriptive case study, this study investigates the views and experiences of 55 Computer and Instructional Technologies Education Department students towards application of project-based learning in an online course. Data gathered through close-ended Likert type questionnaire, open-ended questionnaire and self-evaluation reports revealed that project-based learning method provided learners with gains in terms of comprehension of course content through hands-on experience, developing research skills, improving collaboration and group work skills, and creating something by making use of their imagination and creativity in a fun way.
\end{abstract}

\section{Introduction}

In our age, being technology literate and keeping up with the information society are at the forefront of the obligations brought by the developing and renewed science and technology to individuals. Information technology requires answers to questions such as "Where is the most reliable information and how can I access it?", "How can I integrate my previous knowledge to produce new information?", "How can I reveal the creative function of my intelligence?". In this case, new learning environments should be offered where learners can find answers to these questions and actively produce projects (Yurtluk, 2003). The necessary skills brought by the 21 st century have shifted the main purpose of education system from loading or transferring information to learners into teaching them the ways and skills of accessing the most reliable information in the shortest possible way. As developing networking skills, maintaining collaborative relationships with people, and making decisions as a team are considered essential skills to succeed in the new age, students are now expected to move from passive recipients to active creators and need to learn how to learn (Collins \& Halverson, 2009).

Recently, various teaching models have emerged that put the student in the center and make them more active in education. One of them is the Project Based Learning Model (PjBL), which is a student-centered model that was founded by Klipatrick (1918) in the early twentieth century. Thanks to this model, a creative

\footnotetext{
* Ayse Taskiran, Computer and Instructional Technologies Education Department, Anadolu University, Turkey.

e-mail adresses: aysetaskiran@anadolu.edu.tr
} 
classroom environment is created. It can be ensured that students develop self-confidence, establish relationships between the real world by actively exploring real-world problems, challenges, and concepts, see interdisciplinary relationships, work in individual and collaborative learning environments autonomously and purposefully toward the completion of a project (Dado \& Bodemer, 2017; Edutopia, 2014; Shearer \& Quinn, 1996).

\section{Literature}

Constructivist teaching approach is based on the assumption that students should create the knowledge themselves. John Dewey, one of the modern founders of the constructivist learning approach, pointed out that traditional teaching methods do not coincide with the basic principles of students' development, and that learning should be structured and interpreted by the learner in order to be meaningful, relevant and beneficial to life (cited in Williams, 2017). One of the most obvious methods that can be used in accordance with Dewey's philosophy is the project approach (Glassman \& Whaley, 2000). Considering that this approach aims to make not only the learning process but also the evaluation process more meaningful, $\mathrm{PjBL}$, which is based on process-oriented evaluation rather than product-oriented evaluation, comes to the fore. Standardized achievement tests developed and widely used to measure learning tend to fall short of measuring the type of learning and "high-level skills" that PjBL aims to promote (Conley \& DarlingHammond, 2013). Pellegrino and Hilton (2012) emphasize that process-oriented assessment used in PjBL can facilitate the assessment of difficult-to-measure 21st century competencies such as the capacity to engage in problem solving, critical thinking, and metacognition.

The PjBL, which is one of the applications of the constructivist teaching approach, is a student-centered learning approach that focuses on real-life subjects and practices, emphasizing long-term learning activities rather than short-term practices and teacher-centered lessons in the classroom (Goldman, 2000). PjBL allows students to analyze data, solve problems, and make decisions. It improves their high-level cognitive skills, and increases their sense of responsibility towards their physical and social environment (Dori \& Tal, 2000). In addition, PjBL can help students build and increase their critical thinking skills. Active participation of students in the project process enables them to shape their own ideas and reveal their perspectives (Zoller, 1991). In addition to equipping students with knowledge, PjBL is also effective in developing learners problem-solving skills, creative thinking skills, lifelong learning skills, communication skills, teamwork, adaptation to changes and self-evaluation skills (Khoiri et al., 2013). PjBL, which can include many methods and strategies, is a learning approach that aims to enable students to reach information on their own, use this information and express it by combining it with their own ideas. Educators working on PjBL model define it as a constructive, collaborative learning model that directs students to research and aims to understand the content in depth (Willard \& Duffrin, 2003).

While the mission of higher education institutions is to provide students with cognitive knowledge and professional skills, as well as skills such as problem solving and teamwork (Casner-Lotto \& Barrington, 2006; Vogler et al., 2018), it does not seem possible to reach these goals with a teacher-centered traditional approach (Muganga \& Ssenkusu, 2019). Despite its potentials to enhance problem solving, critical thinking and collaborative skills, PjBL seem to be scarcely applied in higher education context. According to the findings of a 20-year meta-analysis of journal articles on PjBL, the model seems to be more widely applied at the K-12 level (Chen \& Yang, 2019). Among relatively little research focusing on implementation of PjBL in higher education, Torres et al. (2016) found that students who chose a PjBL course on engineering design showed more persistence on to earn a degree in engineering. Analysis of 76 empirical studies focusing on $\mathrm{PjBL}$ application in higher education context revealed that affective outcomes including learner experience and perceptions of the benefits of PjBL were most applied (Guo et al., 2020). Most of the studies conducted in the related field have shown that participation in $\mathrm{PjBL}$ contributes to development of learning strategies (Stefanou, et al., 2013), improves self-efficacy, achievement (Mahasneh \& Alwan, 2018) and content knowledge (Mohamadi, 2018), motivates students to learn (Shih \& Tsai, 2017; Shin, 2018; Wu 
et al., 2018), and provides important skills such as responsibility, cooperation, time management and problem solving (Hall, et al, 2012).

Nowadays, where online learning is gaining importance, it has been possible to use instructional technologies to facilitate collaboration skills. Most of the students have become familiar with using digital technology in their schools. With PjBL, students can use their technological skills to participate in learning activities (Musa et al., 2011). Implementation of PjBL in online higher education context has been the focus of relatively little research. Using PjBL in online learning might be effective in increasing productivity (Heo, Lim, \& Kim, 2010; Shih \& Tsai, 2017). Morales et al. (2013) suggest that PjBL can be effective in an online learning environment even with minimal teacher guidance. In their study, Çakiroğlu and Erdemir (2019) revealed that information technologies facilitate planning, collaboration, communication and individual learning in online project-based design activities. Considering the limited research, how PjBL, one of the best application areas of student-centered learning, can be realized in online learning environments in higher education context and the views of pre-service teachers about this experience are the research subjects of this study. In this connection, the study intended to seek answers for the following research questions:

1. What are the perceptions of the participants regarding:

a) contribution of the PjBL implementation to group work-cooperation skills

b) contribution of the PjBL implementation to research, resource/time management skills

c) contribution of the PjBL implementation to acquiring learning objectives

d) designed learning environment?

2. What are the participants' positive, negative opinions and suggestions regarding the $\mathrm{PjBL}$ implementation in the online course?

3. What are the participants' self-evaluations regarding the project-based online course process?

\section{Methodology}

\subsection{Research Model/Design}

Constructed as a descriptive case study, this study investigates the views and experiences of Computer and Instructional Technologies Education Department students towards application of project-based learning in online Distance Education course. As a research method, case study is used in current situations where there is no researcher control over the variables, and it aims to answer how and why questions allowing in depth examination of a phenomenon or event that the researcher cannot control (Yildirım \& Şimşek, 2011; Yin, 2009). The focus of the case study is to try to describe an event as it exists. The case study differs from other qualitative research methods with its features such as, analyzing a single unit or a bounded system, making intense descriptions and interpreting depending on the context (Hancock \& Algozzine, 2006). A descriptive (also known as illustrative) case study aims to describe the situation descriptively by examining one or more examples (Yin, 1994). The factors affecting education can change depending on the context and people can affect these factors (Yildirım, 1999). It is not possible to examine education systems outside of their real context. For this reason, the case study adopts the understanding that the factors affecting education should be examined in their real contexts. In addition, one of the basic components of the education concept is the process. In educational research, information about the process and how the research group was affected in the process is under consideration. A case study research is used when questions are about the process (Rose et al., 2015). For these reasons, descriptive case study design was employed for this study. 


\subsection{Data Collecting Tools}

The case study does not require the use of a specific data collection method, tool, and data analysis method. Case studies are conducted by collecting data from multiple sources to make in-depth investigations. Researchers need different types of data to develop deep understanding of the situation under study (Creswell, 2011). In this study, as one of the data collecting tools, a questionnaire including 15 close-ended Likert-type statements was used. Likert-type questions were used because they are frequently referenced in fields such as social sciences and education (Edmondson, 2005) and are very easy to apply, code and measure (Spector, 1992). The questionnaire was composed by Dağ and Durdu (2012), and necessary permission from copyright holders was taken. The questionnaire included 3-point Likert type questions ranging from not true ( 1 point), partially true ( 2 points), to true ( 3 points), and it aimed at getting perceptions of learners about four sub-categories that are; group work-cooperation skills (four statements), research, resource/time management skills (five statements), opinions about acquiring learning objectives (three statements), and opinions about designed learning environment (three statements). Also, the participants were given an open-ended questionnaire consisting of three questions regarding their positive, negative ideas and suggestions for $\mathrm{PjBL}$ implementation during their online course. In addition, the participants filled in project self-evaluation forms that included six open-ended questions at the end of the project.

\subsection{Sampling or Study Group}

Participants of the study were 55 Computer and Instructional Technologies Education Department junior and senior students. They were selected using non-random purposeful sampling method in order to reach qualified research objects. Based on this method, participants were included according to the following criteria: (a) active Computer and Instructional Technologies Education Department students, (b) have taken online Distance Education course in 2019 fall semester, 2020 spring semester and 2020 fall semester (c) have completed all requirements of the course that embodied PjBL design.

\subsection{Data Analysis}

Data analysis techniques of the study differed according to the data type. Four sub-categories which included a series of three to five Likert-type items that are combined into a single composite score that represented each sub-category were analyzed with descriptive statistics that included the mean for central tendency and standard deviations for variability (Boone \& Boone, 2012). For the open-ended questionnaire, content analysis was conducted based on the themes of three questions, which were positive opinions, negative opinions and suggestions regarding the implementation of PjBL for the online course. For the selfevaluation form consisting of six open-ended questions, the content analysis was done through coding and reaching more general themes.

\subsection{Validity and Reliability}

Validity and reliability measures of the study were taken according to the types of data collection instruments. For the close-ended Likert-type questionnaire, in order to ensure scope validity, a field expert other than the researchers checked for content. In addition, the items were evaluated by a Turkish language expert in terms of its suitability for Turkish and suggested corrections were made. The reliability of the items was calculated with Cronbach Alpha Internal Consistency following piloting, and Cronbach's Alpha value (Cronbach, 1990) was found to be 0.87 (Dağ \& Durdu, 2012), which revealed that the resulting reliability coefficient was above 0.80 criterion (Bryman \& Cramer, 1997). For the qualitative data, the open-ended questions in self-evaluation form and the questionnaire were constructed with assistance of a qualitative research field expert. Since the open-ended questions might come with a great diversity in answers, two independent researchers took part in the coding process and inter-coder comparisons were made during the data analysis process in order to reach consensus (Strauss \& Corbin, 1998). 


\subsection{Research Procedures}

The study was conducted during three successive semesters in years 2019-2020 at Anadolu University Computer and Instructional Technologies Department. PjBL was implemented for the online Distance Education Course, which was a must course for the program. The course was conducted fully online on Canvas Learning Management System (LMS).

At the beginning of each semester detailed information about the project, syllabus including detailed tasks to be completed on a weekly basis and evaluation principles and rubrics were shared with the students on the LMS. By the end of the semester, the students were supposed to complete an online course design by following the guidelines, audio-visual, interactive and written content shared on the course page, and twohours synchronous classes each week in the form of video-conferencing. At the first stage of the project, the students were allowed to form groups of 3-4 by their own wish. Eight different learner profiles with different age group, professions, time limits they can allocate for the online course, technological possibilities they have and technological literacies were created by the researcher. Each learner profile required a distance online course on a different subject matter. The students were randomly assigned to each learner profile.

For 14 weeks, each aspect of online distance course design was studied synchronously and asynchronously. From the analysis of target audience, course aims and objectives, drafted course syllabus, learning and distance learning theories to instruction methods and techniques, detailed syllabus, learner-teacher roles, teaching materials, teaching media, teaching modes, interaction types and many other components of online course design were covered on LMS. The students were responsible to work in groups to complete the requirements of each week and share their tasks on the LMS. For example, for the first two weeks, each group had to make a labor division to complete their questionnaire / interview questions for the analysis of the target audience task. The example task can be seen in Table 1. After preparing their task, a group member was supposed to upload their reports and plans on the LMS.

Table 1.

Task for the first two weeks

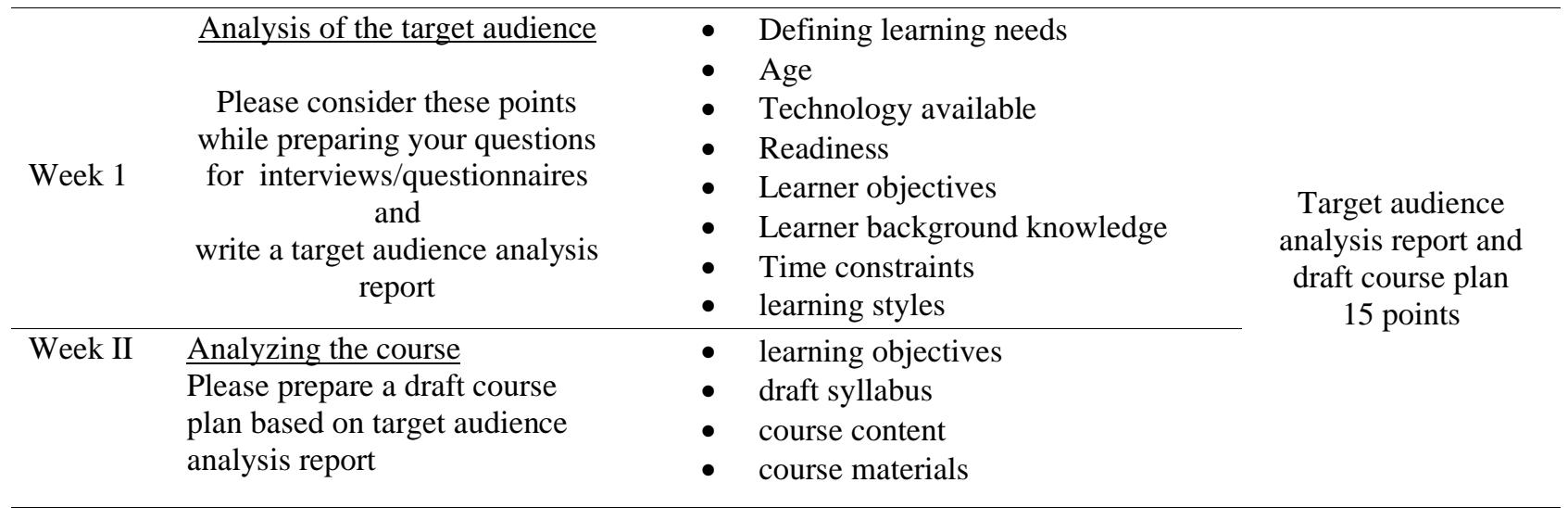

First half of the course design was submitted for the mid-term evaluation. For the final evaluation the students submitted the complete course design, each component of which was explained with justifications based on the Distance Education Course content, and presented their course design in groups in videoconferencing session. During the project the teacher provided guidance and support both synchronously and asynchronously. At the end of the project the participants were given the questionnaires and selfevaluation forms. 


\subsection{Findings and Discussions}

The questionnaire on the perceptions of the participants about the PjBL implementation revealed mostly positive results. Table 2 shows the frequency and the percentage of each statement regarding the contribution of the project to group work and collaboration skills. According to the first statement, $86 \%$ of the students stated that it contributed to the development of group working skills, which is a high ratio compared to those who said no $(11 \%)$ and which is a similar finding in the literature (Dağ \&Durdu, 2012; Dag \& Durdu, 2017; Putri et al., 2017; Shin, 2018). Similarly, most of the participants (76\%) believed the project also contributed to their collaborative working skills and they stated they mostly had good communication as a group. For the third statement, although more than half of the participants $(66 \%)$ believed that the required tasks were carried out by each group member, it is seen that a significant number of students do not share the same thoughts. The fact that group members did not take equal responsibility can be considered as an expected result considering the relevant literature (Dag \& Durdu, 2017; Pinter \& Cisar, 2018). The participants in the study conducted by Pinter and Cisar (2018) most of the students claimed that they noticed certain member contributed more to the success of the project than others. Another study conducted by Aldabbus (2018) revealed that some students dominated the project work and did not let other members in the group to actively participate. Similarly, almost half of the participants in another study did not agree with that the process of project work was carried out equally by each member (Dağ \& Durdu, 2012). In order to solve these and similar problems related to group work and collaboration, students can be closely guided in division of labor by the teacher and also they can be allowed to form groups themselves as done in this study.

Table 2.

Frequencies of responses for group work.

\begin{tabular}{|c|c|c|c|c|c|c|}
\hline \multirow[t]{2}{*}{ Statements } & \multicolumn{2}{|c|}{ not true } & \multicolumn{2}{|c|}{ partially true } & \multicolumn{2}{|c|}{ true } \\
\hline & & $(\%)$ & $\mathbf{N}$ & $(\%)$ & $\mathbf{N}$ & $(\%)$ \\
\hline 1. This project work contributed to the development of my group working skills. & 6 & $(11)$ & 2 & (3) & 47 & $(86)$ \\
\hline 2. This project work contributed to my collaborative working skills. & 6 & $(11)$ & 7 & $(13)$ & 42 & (76) \\
\hline $\begin{array}{l}\text { 3. In this project work, the tasks specified in the project calendar were carried out } \\
\text { equally by each group member. }\end{array}$ & 4 & (7) & 15 & $(27)$ & 36 & (66) \\
\hline 4. We had good communication as a group with this project work. & 10 & $(18)$ & 3 & (6) & 42 & (76) \\
\hline
\end{tabular}

The other sub-category in the questionnaire aimed to reveal the perceptions of pre-service teachers regarding the research and time management skills. Table 3 shows the frequency and percentage of the responses for each statement in this category. Most of the statements did not receive negative response for the contribution of PjBL implementation to research and time management skills and those that received were very few (three for the fourth statement and one for the final statement). Majority of the participants believed that the project work contributed to their research and resource use skills except for the time management skills (47\%). According to the answers given, the point of the project work that is believed to have contributed the most was learning how to select necessary information during the project with $85 \%$. And it was followed by learning to organize the information $(80 \%)$, and time allocated for the project (78\%). For PjBL activities, it is important that learners have sufficient time and opportunities to practice effective communication, technology use, critical thinking and problem solving (Aldabbus, 2018). Considering the time allocated for the project in this study was found to be enough for most of the students, it is seen that the participants experienced challenges regarding managing the given time while carrying out the required tasks. This might be because of not having much experience on projects work, or because of problems with the division of labor. Unlike these findings, majority of students in Belwal et al.'s (2020) study asserted effective time management as the most important contribution of project work. Regarding time management, a difference between Belwal et al.'s study and this one is that the time allocated for the project was quite limited and there were tasks that needed to be completed hourly as participants mentioned. 


\section{Table 3.}

Frequencies of responses for research and time management skills.

\begin{tabular}{|c|c|c|c|c|c|c|}
\hline \multirow[t]{2}{*}{ Statements } & \multicolumn{2}{|c|}{ not true } & \multicolumn{2}{|c|}{ partially true } & \multicolumn{2}{|c|}{ true } \\
\hline & $\mathbf{N}$ & $(\%)$ & $\mathbf{N}$ & $(\%)$ & $\mathbf{N}$ & $(\%)$ \\
\hline 1. This project work helped me to develop my research skills. & 0 & $(0)$ & 17 & $(31)$ & 38 & $(69)$ \\
\hline $\begin{array}{l}\text { 2. In this project work, I learned how to select the necessary information for the } \\
\text { project topic. }\end{array}$ & 0 & $(0)$ & 8 & $(15)$ & 47 & $(85)$ \\
\hline $\begin{array}{l}\text { 3. In this project work, I learned to organize the information I learned about the } \\
\text { subject. }\end{array}$ & 0 & $(0)$ & 11 & $(20)$ & 44 & $(80)$ \\
\hline 4. The time given for this project work was sufficient. & 3 & $(6)$ & 9 & $(16)$ & 43 & (78) \\
\hline 5. Thanks to this project work, I gained time management skills. & 1 & $(2)$ & 28 & $(51)$ & 26 & $(47)$ \\
\hline
\end{tabular}

Third section of the questionnaire focused on the perceptions of the learners about the contribution of project work to acquiring learning objectives. Table 4 shows the frequency of responses for each statement. Findings revealed that none of the statements received a negative response. Majority of the participants responded in favor of the support of the project work to acquiring objectives for the statements $(84 \%, 87 \%$, $80 \%$, respectively). They believed that the project work helped them understand and comprehend the subject matter to a great extent. PjBL is believed to be an effective method for learning for reasons, such as that the whole class revises the topic studied (Salybekova, 2021), project work stimulates the student's curiosity towards the subject matter (McManus, \& Costello, 2019), increases active participation and motivation, makes the lesson more understandable, meaningful and the learning more permanent (Çelik et al., 2018; Şahin et al., 2020), and it involves authentic learning tasks (Eskrootchi \& Oskrochi, 2010).

\section{Table 4.}

Frequencies of responses for acquiring learning objectives.

\begin{tabular}{|c|c|c|c|c|c|c|}
\hline Statements & $\begin{array}{l}\text { no } \\
\text { N }\end{array}$ & $\begin{array}{l}\text { true } \\
(\%)\end{array}$ & $\begin{array}{c}\text { par } \\
\mathbf{N}\end{array}$ & $\begin{array}{l}\text { ially true } \\
(\%)\end{array}$ & tru & e $(\%)$ \\
\hline $\begin{array}{l}\text { 1. This project work allowed me to understand and comprehend the stages of distance } \\
\text { education course design. }\end{array}$ & 0 & (0) & 9 & (16) & 46 & (84) \\
\hline $\begin{array}{l}\text { 2. This project work helped me learn what to do in the analysis phase of the distance } \\
\text { education course design. }\end{array}$ & 0 & $(0)$ & 7 & (13) & 48 & (87) \\
\hline $\begin{array}{l}\text { 3. This project work contributed to my understanding of the elements to be } \\
\text { considered in the design phase of the distance education course. }\end{array}$ & 0 & $(0)$ & 11 & (20) & 44 & (80) \\
\hline
\end{tabular}

The final sub-category in the questionnaire focused on learner perceptions of the learning environment. Table 5 shows the frequency of responses for each statement. Similar to the other sub-categories, majority of the participants were satisfied with the project work in terms learning process. They believed that the project contributed to their academic success as they were engaged in learning by doing and experiencing. Similarly, Chen and Yang's (2019) meta-analysis of the effects of the PjBL method on academic achievement compared to traditional methods revealed that the method had an average to higher positive effect on academic achievement. According to findings of similar studies, project-based learning contributes to higher levels of perception and learning by creating an effective classroom environment and ensures high student achievement and performance (Belwal et al., 2020; Cifci, 2015; Çelik et al., 2018; Hugerat, 2016). Participants in another study stated that to the research findings PjBL method increases active participation, makes the lesson comprehensible, efficient, instructive, motivating, and makes learning permanent (Şahin et al., 2020). 


\section{Table 5.}

Frequencies of responses for learning environment.

\begin{tabular}{|c|c|c|c|c|c|c|}
\hline \multirow[t]{2}{*}{ Statements } & \multicolumn{2}{|c|}{ not true } & \multicolumn{2}{|c|}{ partially true } & \multicolumn{2}{|c|}{ true } \\
\hline & $\mathbf{N}$ & $(\%)$ & $\mathbf{N}$ & $(\%)$ & $\mathbf{N}$ & $(\%)$ \\
\hline 1. I think that the information I learned during this project work is permanent. & 3 & $(5)$ & 8 & $(15)$ & 44 & $(80)$ \\
\hline 2. This project work allowed me to learn by doing and experiencing information. & 3 & $(5)$ & 13 & (24) & 39 & $(71)$ \\
\hline 3. I think this project work has a positive effect on my course success.. & 0 & $(0)$ & 10 & $(18)$ & 45 & $(83)$ \\
\hline
\end{tabular}

When descriptive statistics showing the means and standard deviations of all sub-categories are examined in order to evaluate the general perceptions of the participants towards $\mathrm{PjBL}$ method, it is seen that the general perception is mostly positive with the mean scores of 2.70 for research skills, 2.64 for group work skills, 2.83 for acquiring learning objectives, and 2.73 for perception regarding the designed learning environment. The findings can be seen in Table 6. In this context, it can be said that the findings show similarities with the relevant literature (Dag \& Durdu, 2017; Guo et al., 2020; Putri et al., 2017; Torres et al., 2016).

\section{Table 6.}

Descriptive statistics for the mean scores of the sub-categories.

\section{Descriptive Statistics}

\begin{tabular}{llllll}
\hline & $\mathrm{N}$ & Minimum & Maximum & Mean & Std. Deviation \\
\hline Research Skills & 55 & 2.00 & 3.00 & 2.70 & .307 \\
Group Work & 55 & 1.00 & 3.00 & 2.64 & .611 \\
Objectives & 55 & 2.00 & 3.00 & 2.83 & .293 \\
Learning Environment & 55 & 1.33 & 3.00 & 2.73 & .447 \\
Valid N (listwise) & 55 & & & & \\
\hline
\end{tabular}

Qualitative findings based on three open-ended questions revealed participants' positive, negative opinions and suggestions for implementation of PjBL in online courses. Table 7 shows the codes, sub-themes and themes regarding each question. In general, participants reported significantly more positive opinions than negative ones. Similarly, they made very few suggestions for the implementation of PjBL in their online course. Positive opinions included gaining collaboration, group work, and time management skills, learning by experience, contribution to individual learning, providing course subject revision, effective learning, effective evaluation, formative feedback, flexibility, fun, and effective instruction. Different from this study, most PjBL studies are conducted in face-to-face learning contexts. Considering this difference, the findings of the relevant literature showed similarities with this one. Findings of Shin's (2018) study revealed that project-based learning has advantages in students' motivation to learn, attention, relevance, collaborative learning. In the same way, participants in Şahin et al.'s (2020) study found PjBL implemented course instructive, effective, motivating and fun. Regarding effective learning, one of the participants in this study stated that "I think that since we learn by designing and making an instructional design, instead of instruction of the theoretical information in a straight way by the teacher, the information I have gained will be permanent". The participants believe that learning by doing contributes to meaningful and effective learning. Another participant points out the effect of the project work on revision of the subject matter by stating that "The project was a very instructive project as it required us to go through everything we talked about in the lecture for the entire semester". One participant highlighted that "it was a lot more effective evaluation technique than the exams". As highlighted by Pellegrino and Hilton (2012), process-oriented assessment used in $\mathrm{PjBL}$ makes it possible to assess difficult-to-measure 21st century competencies such as the capacity to engage in problem solving, critical thinking, and metacognition, most of which might not be possible through standardized achievement tests. About the academic gains and group work skills, another participant expressed that "I thought I really learned something while doing this project. I think 
it's the first time I put the knowledge I learned into practice. We have a full understanding of the concepts of group work and collaboration. It was quite successful. Of course, it can't be perfect work. but I think we've laid the foundations for great work". It might be concluded that, with its process-oriented nature, $\mathrm{PjBL}$, the learners appreciated their gains during the process and valued their efforts. Negative opinions expressed by the participants included managing time, adjustment problems in the groups and long and tiring process, yet one participant stated that " In some stages, I had a lot of difficulty and got exhausted, but I learned very well". Tiring process can be appreciated and valued by the participants when learning achieved. Among the suggestions were receiving feedback more often and based on each group's phase. This also shows that formative feedback is valued by the learners as long as it is provided timely.

\section{Table 7.}

Participants' positive and negative opinions, and suggestions for the implementation of PjBL.

\begin{tabular}{|c|c|c|}
\hline Themes & Sub-themes & Codes \\
\hline $\begin{array}{l}\text { Positive } \\
\text { opinions }\end{array}$ & $\begin{array}{l}\text { collaboration } \\
\text { group work } \\
\text { flexibility } \\
\text { formative feedback } \\
\text { learning by experience } \\
\text { contribution to individual learning } \\
\text { revision } \\
\text { fun } \\
\text { effective evaluation } \\
\text { effective learning } \\
\text { time management } \\
\text { experience } \\
\text { effective instruction }\end{array}$ & $\begin{array}{l}\text { positive effect of the collaborative work } \\
\text { positive effect of working with group } \\
\text { improvement of group work skills } \\
\text { full understanding of group consciousness, cooperation } \\
\text { no stress for deadlines } \\
\text { allocation of enough time } \\
\text { receiving feedback on time } \\
\text { better comprehension with feedback } \\
\text { self-correction with constructive feedback } \\
\text { learning by designing and making } \\
\text { transferring theory into practice } \\
\text { learning by oneself } \\
\text { instructive project } \\
\text { going through the course content } \\
\text { a lot fun to work together } \\
\text { more effective evaluation than exams } \\
\text { really learning something } \\
\text { putting learned information into practice } \\
\text { gaining time-management skills } \\
\text { gaining life-long experience } \\
\text { learning details about the course subject } \\
\text { informative course design }\end{array}$ \\
\hline $\begin{array}{l}\text { Negative } \\
\text { opinions }\end{array}$ & $\begin{array}{l}\text { time management } \\
\text { group work } \\
\text { tiresome process }\end{array}$ & $\begin{array}{l}\text { having problems with time management } \\
\text { adjustment problems within group } \\
\text { not getting along with group members } \\
\text { lack of communication in the group } \\
\text { long and labored process }\end{array}$ \\
\hline Suggestions & $\begin{array}{l}\text { feedback } \\
\text { grouping }\end{array}$ & $\begin{array}{l}\text { getting earlier feedback for groups that progress quickly } \\
\text { receiving feedback weekly } \\
\text { random assignment of group members }\end{array}$ \\
\hline
\end{tabular}

Content analysis of the self-evaluation form consisting of six open-ended questions revealed learners' perceptions about their gains, performance self-evaluation, the most challenging part of the project for them, and what parts they enjoyed most. Table 8 shows the codes, sub-themes and themes regarding each question. 


\section{Table 8.}

Participants' self-evaluations

\begin{tabular}{|c|c|c|}
\hline Themes & Codes & Important Statements \\
\hline Gains & $\begin{array}{l}\text { awareness towards course content } \\
\text { importance of communication in the group } \\
\text { nature of group work } \\
\text { significance of planning } \\
\text { collaboration with other members } \\
\text { putting theory into practice by doing } \\
\text { importance or research steps }\end{array}$ & $\begin{array}{l}\text { I had the opportunity to associate the course content with real life and } \\
\text { this impressed me a lot, I liked this awareness. } \\
\text { I learned very well the importance of communication and how } \\
\text { teamwork should be. } \\
\text { - Ability to work in a planned manner with groupmates } \\
\text { I learned that you can do a nice group assignment with people you } \\
\text { don't know very well. } \\
\text { To learn completely how to design a distance education course, which } \\
\text { is the subject of this course. } \\
\text { I put all my knowledge into practice, I had the chance to apply what I } \\
\text { learned. } \\
\text { I learned that it is necessary to plan the research steps in detail. }\end{array}$ \\
\hline Regrets & $\begin{array}{l}\text { not making a better presentation } \\
\text { paying less attention to some steps } \\
\text { dealing with communication problems } \\
\text { spending less time on presentation } \\
\text { misunderstanding some steps } \\
\text { no regrets at all }\end{array}$ & $\begin{array}{l}\text { I like presentations that try to tell something independent of the } \\
\text { content. I could have done that kind of scenario, my presentation could } \\
\text { have been more colorful. } \\
\text { I think I spent less time than necessary on some parts of the project. } \\
\text { - I tried to create dynamism and increase interaction within the group. } \\
\text { Instead, I wish I had more control over the subject. } \\
\text { - I wish I had listened more carefully while the project phases were } \\
\text { explained. } \\
\text { - I wish I had done some parts correctly, which we learned that we did } \\
\text { wrong with the feedback from the teacher. } \\
\text { - I have no regrets regarding the project, I am content with it. }\end{array}$ \\
\hline $\begin{array}{l}\text { Best } \\
\text { performance }\end{array}$ & $\begin{array}{l}\text { in different stages of the course design } \\
\text { in writing the project report } \\
\text { in presentation stage }\end{array}$ & $\begin{array}{l}\text { - The first step of the distance course design, learner analysis, which is } \\
\text { the subject of the project, went very smoothly. And I think it's } \\
\text { successful. } \\
\text {-I showed the best performance in writing the project report part. } \\
\text {-My friends and I did very well in the presentation stage. }\end{array}$ \\
\hline Challenges & $\begin{array}{l}\text { certain parts of the course content } \\
\text { dealing with group members } \\
\text { presentation stage } \\
\text { putting all things together } \\
\text { studying online }\end{array}$ & $\begin{array}{l}\text {-It was somehow hard to understand theories of distance education. } \\
\text {-Couldn't attend the online group meetings and so missed some } \\
\text { important parts. } \\
\text {-Dealing with group members was really exhausting. } \\
\text {-The project took so long so I had some trouble with putting all the } \\
\text { things together in the end. } \\
\text { - It was very difficult to find a time suitable for everyone for the group } \\
\text { members. } \\
\text {-Working on the project online was not easy. }\end{array}$ \\
\hline Fun & $\begin{array}{l}\text { designing and building the project } \\
\text { opportunity to reflect individual } \\
\text { originality } \\
\text { unlimited use of imagination } \\
\text { working with friends } \\
\text { the whole process } \\
\text { the presentation stage } \\
\text { studying online } \\
\text { becoming aware of one's achievement }\end{array}$ & $\begin{array}{l}\text { - It was so much fun doing everything from scratch, step by step. } \\
\text { - It was a pleasure to be able to add our own original ideas to the project, } \\
\text { to add our imagination and creativity. } \\
\text { - It was fun to have unlimited imagination when we were editing. } \\
\text { - It was very enjoyable to work with my dear friends, we had a lot of } \\
\text { fun. } \\
\text { - I enjoyed the whole process very much. } \\
\text { - We were all excited while preparing the presentation. There was an } \\
\text { idea coming from every one of us. We enjoyed the presentation very } \\
\text { much. } \\
\text { - It was great to be able to succeed, to be able to create a distance } \\
\text { education course design. }\end{array}$ \\
\hline $\begin{array}{l}\text { Evaluation } \\
\text { of } \\
\text { Performance }\end{array}$ & $\begin{array}{l}\text { doing one's best } \\
\text { showing great performance } \\
\text { effective learning process } \\
\text { need to study more systematically } \\
\text { making revisions more often }\end{array}$ & $\begin{array}{l}\text { - I believe I did my best. } \\
\text { - I did not expect this much, but I can say that I surpassed myself. } \\
\text { - It was an extremely productive process, I actively participated in every } \\
\text { step and it was an effective learning for me. } \\
\text { - I couldn't pay attention at some stages, I neglected it, I should have } \\
\text { worked more planned and systematically. } \\
\text { - In fact, we were expected to put the topics we covered into practice, } \\
\text { but my performance was low because I did not make enough revisions. }\end{array}$ \\
\hline
\end{tabular}


Based on the statements of the participants, it can be concluded that the group project work seemed to create awareness of group work dynamics, planning, time management, course content, transfer of knowledge. Findings indicate that there are certain gains regarding the course content and project skills such as planning, group work, time management. Also, regrets are mostly about not paying much attention or neglecting responsibilities. That is, regrets were not about the project work itself. Most challenges experienced by the participants were centered around the problems with working in groups. This might be due to lack of experience in group work. It might be a good solution to make an orientation on the basic principles of working as a group before the project starts. In-group evaluation checklists that can be performed by group members at the end of each stage can also be a solution. The participants in Aldabbus' (2018) study mentioned similar challenges and findings showed that students lacked the necessary skills of collaborative work. Fleming (2000) lists six features of project-based learning as; 1. original problem, 2. student selection, 3. academic process, 4. hands-on learning beyond the school walls, 5. a unique product, 6. transparent evaluation practices using predetermined criteria. The participants of this study also mentioned most of these features in self-evaluation forms by pointing out the gains regarding the comprehension of the subject matter through active participation, putting what is learned into practice, creating original work by using individual effort and creativity. It is possible to suggest that the PjBL positively affected the academic achievement as participants made comments regarding the effectiveness of learning process and awareness of their performance. Similar to these findings, other PjBL studies show that project works improve enthusiasm, confidence, creativity, self-directed learning and collaborative learning skills (Astawa et al., 2017; Chen \& Yang, 2019; Çelik et al., 2018; Mahasneh \& Alwan, 2018)

\section{Conclusion and Suggestions}

According to the findings of this study, the implementation of PjBL method in online learning environments has certain contributions to the learning process. First of all, it allows students to work with groups, and therefore contributes to improvement of their group work and cooperation skills. Majority of the participants claimed that the project work contributed to the development of group working skills. During the learning process learners had a chance to experience what collaboration and group work was and how it should be done through first-hand experience. Some challenges regarding working in groups were about group members' taking inequal responsibility and communication problems within the group, which are among the common findings in the relevant literature (Dag \& Durdu, 2017; Pinter \& Cisar, 2018). Although this study let participants to form groups on their own, some responses indicated complaints about the group dynamics and sharing responsibility within the group and lack of communication. Some suggestions from participants were about random assignment of group members. An implication of this finding can be applying group work orientation at the beginning of the project. Teachers might instruct the general principles of group work, the importance of sharing equal responsibility and introduce group task completion checklists, which would allow more close monitoring on completion of tasks by all group members.

In addition, majority of the participants believed that the project work contributed to their research and resource use skills. Learners' responses indicated that most of them became aware of the managing time effectively and significance of planning each step of the project carefully, which was a finding supported by current research (e.g. Ruslan et al., 2021; Santoso et al, 2021). Some challenges regarding ineffective use of time were also on mentioned by the participants and they stated heightened awareness towards the importance of planning and managing time during the project, which is another similar finding (Aldabbus, 2018).

Furthermore, based-on the quantitative and qualitative data, it can be concluded that $\mathrm{PjBL}$ implementation in online learning contributes to acquisition of learning objectives by doing and experiencing. The project work in this study focused on creating a distance course design. Participants' responses indicated that they 
mostly achieved the learning objectives of the course. Accordingly, learners emphasized that they could comprehend the content of the course by applying gained information into practice. Moreover, most of the participants believed that their gains would be permanent. This is one of the most common findings in PjBL literature (Chen \& Yang, 2019; Çelik et al. ,2018; Santyasa et al, 2020; Syakur et al., 2020). Participants of this study expressed a lot more positive opinions compared to negative ones about the implementation of $\mathrm{PjBL}$ in their online Distance Education course. In the same way, they expressed few suggestions for the planning a better implementation of PjBL in their online course. Asserted positive opinions such as gaining collaboration, group work, and time management skills, learning by experience, contribution to individual learning, providing course subject revision, effective learning, effective evaluation, fun, and effective instruction were quite common int he relevant literature (Chen \& Yang, 2019; Pellegrino \& Hilton, 2012; Shin, 2018, Şahin et al, 2020). Negative opinions were mostly about not managing time effectively and communication problems within the groups. Difficulties in group works, inability to meet in common ideas, problems in setting up a common time, and members' not fulfilling responsibilities were among the challenges experienced by the participants in similar studies (e.g., Dag \& Durdu, 2017; Pinter \& Cisar, 2018; Şahin et al, 2020; ). Pawson et al (2006) draws attention to this common problem in PjBL implementation by emphasizing that these problems originate from the lack of experience in joint learning and a lack of skills required for this type of learning. An implication of this finding can be setting a project orientation stage that covers sharing information, discussing the project, dividing tasks on each group member and preparing task completion checklists.

Despite the challenges, the findings in general indicate that PjBL implementation in the online course provided learners with gains in terms of comprehension of course content through hands-on experience, developing research skills, improving collaboration and group work skills, and creating something by making use of their imagination and creativity in a fun way. Whether online or face-to-face, PjBL has proven the potentials of effective teaching and learning process. This method has shown that it is effective not only in creating awareness on the significance of learning process, but also in raising awareness about the individual capabilities, achievements and the importance of planning, good communication and taking responsibility in the research process. As an effective method for gaining and measuring 21 st century skills, $\mathrm{PjBL}$ stands out as a useful method in online teaching. It may be possible to create an effective learning process with the contribution of good planning, orientation, close process monitoring, and formative feedback given in a timely manner.

\section{Limitations and Suggestions for Further Research}

This study was limited by focusing on perceptions of limited number of learners taking the same online course. Future researchers might conduct mixed-research studies targeting students and teachers who are engaged in online PjBL for different courses with multiple data collection tools for both groups based upon the findings of this study. Also, this study is limited to the perceptions of learners. Investigating perceptions of teachers towards online $\mathrm{PjBL}$ implementation and teachers' unique methods for realizing $\mathrm{PjBL}$ in online teaching contexts might shed light on the relevant literature.

\section{References}

Aldabbus, S. (2018). Project-based learning: Implementation \& challenges. International Journal of Education, Learning and Development, 6(3), 71-79.

Belwal, R., Belwal, S., Sufian, A.B., \& Al Badi, A. (2020). Project-based learning (PBL): outcomes of students' engagement in an external consultancy project in Oman. Education and Training, 63(3), 336-359.

Boone, H. N., \& Boone, D. A. (2012). Analyzing likert data. Journal of Extension, 50(2), 1-5 
Bryman, A. and Cramer, D., (1997). Quantitative data analysis with SPSS for Windows: A guide for social scientists. London: Routledge.

Casner-Lotto, J., \& Barrington, L. (2006). Are they really ready to work? Employers' perspectives on the basic knowledge and applied skills of new entrants to the 21st century US workforce. Partnership for 21st Century Skills. 1 Massachusetts Avenue NW Suite 700, Washington, DC 20001.

Chen, C. H., \& Yang, Y. C. (2019). Revisiting the effects of project-based learning on students' academic achievement: A meta-analysis investigating moderators. Educational Research Review, 26, 71-81.

Collins, A., \& Halverson, R. (2009). Rethinking education in the age of technology: The digital revolution and schooling in America. New York: Teachers College Press.

Conley, D. T., and Darling-Hammond, L. (2013). Creating systems of assessment for deeper learning. Stanford, CA: Stanford University, Stanford Center for Opportunity Policy in Education.

Cronbach, LJ (1990). Essentials in psychological testing (5th ed.). New York: Harper Collins.

Ciftci, S. (2015). The effects of using project-based learning in social studies education to students' attitudes towards social studies courses. Procedia-Social and Behavioral Sciences, 186, 1019-1024.

Çakiroğlu, Ü., \& Erdemir, T. (2019). Online project based learning via cloud computing: exploring roles of instructor and students. Interactive Learning Environments, 27(4), 547-566.

Çelik, H. C., Ertas, H., \& İlhan, A. (2018). The Impact of Project-Based Learning on Achievement and Student Views: The Case of AutoCAD Programming Course. Journal of Education and Learning, 7(6), 67-80.

Dado, M., \& Bodemer, D. (2017). A review of methodological applications of social network analysis in computer-supported collaborative learning. Educational Research Review, 22, 159-180.

Dağ, F., \& Durdu, L. (2012). Öğretmen adaylarının proje tabanlı öğrenmeye yönelik görüşleri. E-journal of New World Sciences Academy, 7(1).

Dag, F., \& Durdu, L. (2017). Pre-Service Teachers' Experiences and Views on Project-Based Learning Processes. International Education Studies, 10(7), 18-39.

Dori, Y. J., \& Tal, R. T. (2000). Formal and informal collaborative projects: Engaging in industry with environmental awareness. Science Education, 84(1), 95-113.

Edmondson, D. (2005, May). Likert scales: A history. In Proceedings of the Conference on Historical Analysis and Research in Marketing (Vol. 12, pp. 127-133).

Eskrootchi, R., \& Oskrochi, G. R. (2010). A study of the efficacy of project-based learning integrated with computer-based simulation - STELLA. Educational Technology \& Society, 13(1), 236-245.

Fleming, D. S. (2000). A teacher's guide to project-based learning. West Virginia: AEL.

Guo, P., Saab, N., Post, L. S., \& Admiraal, W. (2020). A review of project-based learning in higher education: Student outcomes and measures. International Journal of Educational Research, 102, 101586.

Hall, W., Palmer, S., \& Bennett, M. (2012). A longitudinal evaluation of a project-based learning initiative in an engineering undergraduate programme. European Journal of Engineering Education, 37, 155165.

Heo, H., Lim, K. Y., \& Kim, Y. (2010). Exploratory study on the patterns of online interaction and knowledge co-construction in project-based learning. Computers \& Education, 55(3), 1383-1392. 
Hugerat, M. (2016). How teaching science using project-based learning strategies affects the classroomlearning environment. Learning Environments Research, 19(3), 383-395.

Khoiri, W., Rochmad, R., \& Cahyono, A. N. (2013). Problem Based Learning Berbantuan Multimedia dalam Pembelajaran Matematika Untuk Meningkatkan Kemampuan Berpikir Kreatif. Unnes Journal of Mathematics Education, 2(1), 25-30.

Klipatrick, W.H. (1918). The Project Method. Teachers college record, x1x,4, 319-335.

Mahasneh, A. M., \& Alwan, A. F. (2018). The Effect of Project-Based Learning on Student Teacher SelfEfficacy and Achievement. International Journal of Instruction, 11(3), 511-524.

McManus, J. W., \& Costello, P. J. (2019). Project based learning in computer science: a student and research advisor's perspective. Journal of Computing Sciences in Colleges, 34(3), 38-46.

Mohamadi, Z. (2018). Comparative effect of project-based learning and electronic project-based learning on the development and sustained development of english idiom knowledge. Journal of Computing in Higher Education, 30(2), 363-385.

Morales, T. M., Bang, E., \& Andre, T. (2013). A one-year case study: Understanding the rich potential of project-based learning in a virtual reality class for high school students. Journal of Science Education and Technology, 22(5), 791-806.

Muganga, L., \& Ssenkusu, P. (2019). Teacher-Centered vs. Student-Centered: An Examination of Student Teachers' Perceptions about Pedagogical Practices at Uganda's Makerere University. Cultural and Pedagogical Inquiry, 11(2), 16-40.

Musa, F., Mufti, N., Latif, R. A., \& Amin, M. M. (2011). Project-based learning: Promoting meaningful language learning for workplace skills. Procedia-Social and Behavioral Sciences, 18, 187-195

Pawson, E., Fournier, E., Haigh, M., Muniz, O., Trafford, J. and Vajoczki, S. (2006). Problem-Based Learning in Geography: Towards a Critical Assessment of its Purposes, Benefits and Risks. Journal of Geography in Higher Education, 30(1), pp. 103-116.

Pellegrino, J. W., and Hilton, M. L. (Eds.). (2012). Education for life and work: Developing transferable knowledge and skills in the 21st century. Washington, DC: National Academies Press.

Pinter, R., \& Cisar, S. M. (2018). Measuring Team Member Performance in Project Based Learning. Journal of Applied Technical and Educational Sciences, 8(4), 22-34.

Putri, N. L. P. N. S., Artini, L. P., \& Nitiasih, P. K. (2017). Project-based learning activities and EFL students' productive skills in English. Journal of Language Teaching and Research, 8(6), 11471155 .

Ruslan, M. S. H., Bilad, M. R., Noh, M. H., \& Sufian, S. (2021). Integrated project-based learning (IPBL) implementation for first year chemical engineering student: DIY hydraulic jack project. Education for chemical engineers, 35, 54-62.

Salybekova, N., Issayev, G., Abdrassulova, Z., Bostanova, A., Dairabaev, R., \& Erdenov, M. (2021). Pupils' research skills development through project-based learning in biology. Cypriot Journal of Educational Sciences, 16(3), 1106-1121.

Santoso, A. M., Primandiri, P. R., Zubaidah, S., \& Amin, M. (2021, March). The development of students' worksheets using project based learning (PjBL) in improving higher order thinking skills (HOTs) and time management skills of students. In Journal of Physics: Conference Series (Vol. 1806, No. 1, p. 012173). IOP Publishing. 
Santyasa, I. W., Rapi, N. K., \& Sara, I. (2020). Project based learning and academic procrastination of students in learning physics. International Journal of Instruction, 13(1), 489-508.

Shih, W. L., \& Tsai, C. Y. (2017). Students' perception of a flipped classroom approach to facilitating online project-based learning in marketing research courses. Australasian Journal of Educational Technology, 33(5).

Shin, M. H. (2018). Effects of project-based learning on students' motivation and self-efficacy. English Teaching, 73(1), 95-114.

Spector, P. E. (1992). Summated rating scale construction: An introduction. Newbury Park, CA: Sage.

Stefanou, C., Stolk, J. D., Prince, M., Chen, J. C., \& Lord, S. M. (2013). Self-regulation and autonomy in problem-and project-based learning environments. Active Learning in Higher Education, 14(2), $109-122$.

Strauss, A. and Corbin, J. (1998). Basics of qualitative research: Techniques and procedures for developing grounded theory. California: Sage Publications.

Syakur, A., Musyarofah, L., Sulistiyaningsih, S., \& Wike, W. (2020). The effect of project based learning (PJBL) continuing learning innovation on learning outcomes of english in higher education. Budapest International Research and Critics in Linguistics and Education Journal, 3(1), 625-630.

Şahin, Ş., Ökmen, B., \& Kılıç, A. (2020). Karakter ve Değerler Eğitimi Dersinin Proje Tabanlı Öğrenmeye Göre Düzenlenmesi. Ondokuz Mayıs Üniversitesi Eğitim Fakültesi Dergisi, 39(2), 360-384.

Torres, W. J., Saterbak, A., \& Beier, M. E. (2016). Long-term impact of an elective, first-year engineering design course. New Orleans, LA: American Society for Engineering Education

Williams, M. K. (2017). John Dewey in the 21st century. Journal of Inquiry and Action in Education, 9(1), 7.

Wu, T. T., Huang, Y. M., Su, C. Y., Chang, L., \& Lu, Y. C. (2018). Application and analysis of a mobile E-Book system based on project-based learning in community health nursing practice courses. Journal of Educational Technology \& Society, 21(4), 143-156.

Vogler, J. S., Thompson, P., Davis, D. W., Mayfield, B. E., Finley, P. M., \& Yasseri, D. (2018). The hard work of soft skills: augmenting the project-based learning experience with interdisciplinary teamwork. Instructional Science, 46(3), 457-488.

Yıldırım, A. ve Şimşek, H. (2011). Sosyal bilimlerde nitel araştırma yöntemleri (8. Baskı). Ankara: Seçkin Yayıncılık.

Yin, R.K. (2009). Case study methods: design and methods (4. Bask1). Thousand Oaks: Sage Pbc.

Yurtluk, M. (2003). Proje tabanlı öğrenme yaklaşımının matematik dersi öğrenmes ve öğrenci tutumlarına etkisi. Yayınlanmamış yüksek lisans tezi, Hacettepe Üniversitesi, Ankara.

Zoller, H. U. (1991). Problem solving and problem solving paradox in decision-making-oriented environmental education. In S. Keiny and U. Zoller (eds) Conceptual Issues in Environmental Education. New York: Peter Lang, 71-87. 